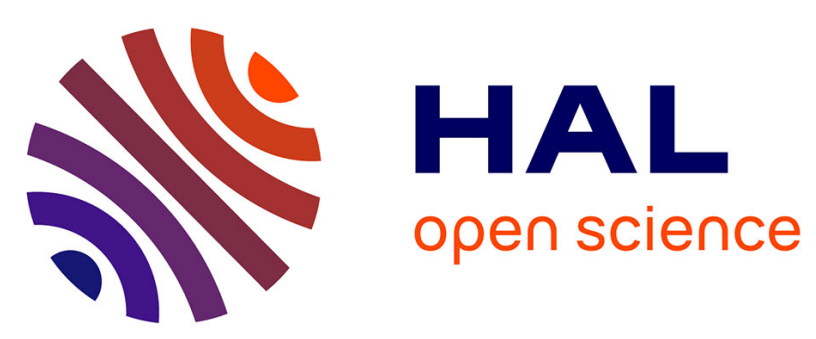

\title{
Effect of operating conditions on Ochratoxin A extraction in roasted coffee
}

Pauline Mounjouenpou, Noël Durand, Bernard Guyot, Joseph Guiraud

\section{To cite this version:}

Pauline Mounjouenpou, Noël Durand, Bernard Guyot, Joseph Guiraud. Effect of operating conditions on Ochratoxin A extraction in roasted coffee. Food Additives and Contaminants, 2007, 24 (07), pp.730734. 10.1080/02652030701199972 . hal-00577542

\section{HAL Id: hal-00577542 \\ https://hal.science/hal-00577542}

Submitted on 17 Mar 2011

HAL is a multi-disciplinary open access archive for the deposit and dissemination of scientific research documents, whether they are published or not. The documents may come from teaching and research institutions in France or abroad, or from public or private research centers.
L'archive ouverte pluridisciplinaire HAL, est destinée au dépôt et à la diffusion de documents scientifiques de niveau recherche, publiés ou non, émanant des établissements d'enseignement et de recherche français ou étrangers, des laboratoires publics ou privés. 


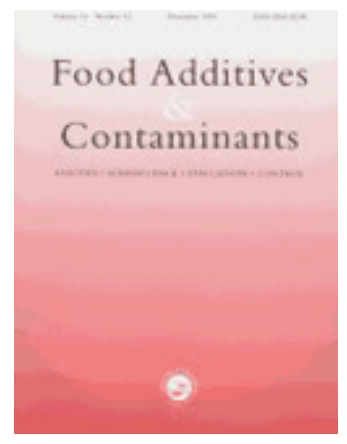

\section{Effect of operating conditions on Ochratoxin A extraction in roasted coffee}

\begin{tabular}{|r|l|}
\hline Journal: & Food Additives and Contaminants \\
\hline Manuscript ID: & TFAC-2006-282.R1 \\
\hline Manuscript Type: & Original Research Paper \\
\hline Author: & 21-Dec-2006 \\
\hline Complete List of Authors: & $\begin{array}{l}\text { Mounjouenpou, Pauline; Institut de Recherche Agricole pour le } \\
\text { Développement } \\
\text { Durand, Noël; CIRAD-CP, UR33 } \\
\text { Guyot, Bernard; CIRAD-CP, UR33 } \\
\text { Guiraud, Joseph; Université Montpellier 2, UMR IR2B }\end{array}$ \\
\hline Methods/Techniques: & Chromatography - HPLC, Extraction \\
\hline Additives/Contaminants: & Ochratoxin A \\
\hline Food Types: & Coffee \\
\hline & $\quad$ SCHOLARONE ${ }^{\text {M }}$ \\
\hline & \\
&
\end{tabular}




\section{Effect of operating conditions on ochratoxin A extraction 2 from roasted coffee}

3

4 PAULINE MOUNJOUENPOU ${ }^{1}$, NOËL DURAND ${ }^{2}$, BERNARD GUYOT $^{2}$, 5 AND JOSEPH P. GUIRAUD ${ }^{3 *}$

6

7 Institut de Recherche Agricole pour le Développement, BP 2067, Yaoundé, Cameroon ${ }^{1}$,

8 Unité de Recherche 33, CIRAD-CP TA80/16, 34398 Montpellier Cedex 5, France ${ }^{2}$, and

9 UMR-IR2B (Agro-M/INRA/UM2), Université Montpellier II, Place Eugène Bataillon, 34095

10 Cedex 5, France ${ }^{3}$.

11

12 Running title: OTA Extraction in Roasted Coffee

13 * Author to whom correspondence should be addressed : Joseph-Pierre Guiraud; e-mail :

14 guiraud@univ-montp2.fr 


\section{Abstract}

16 Operating conditions affect ochratoxin A (OTA) extraction from roasted coffee. The OTA

17 content found in the beverage can thus be greater than that found in the roasted coffee used to

18 prepare it. Three extraction parameters were studied for roasted coffee : type of extraction

19 solvent (alkaline, neutral, acid), temperature (ambient temperature $/ 23^{\circ} \mathrm{C}, 60^{\circ} \mathrm{C}$ and $85^{\circ} \mathrm{C}$ ) and

20 extraction time $(5,20,30,40,50,60$ and $80 \mathrm{~min})$. The alkaline solvent that is used in the

21 method recommended by the European Union, extracted OTA better, but a maximum content

22 was obtained at $60^{\circ} \mathrm{C}$ after $50 \mathrm{~min}$. At least a $100 \%$ improvement in extraction was obtained

23 when compared to the EU usual quantification method that is carried out at ambient

24 temperature. It turned out that the OTA extraction parameters for roasted coffee, as defined by

25 that method, were not optimum and needed to be modified. These results were verified in

26 double extraction experiments showing that OTA is not completely extracted by this method.

27 Confirmation was obtained by comparison of extraction methods on several commercial 28 samples of roasted coffee.

\section{$29 \quad$ Keywords}

30 Roasted coffee; OTA extraction; ochratoxin A 


\section{Introduction}

32 Ochratoxin A (OTA) is a mycotoxin produced by moulds of the genera Aspergillus and 33 Penicillium. In coffee, the OTA-producing strains most frequently found are Aspergillus 34 niger, Aspergillus carbonarius and Aspergillus ochraceus (Frank 2001; Joosten et al. 2001; 35 Suàrez-Quiroz et al. 2004). OTA has nephrotoxic, immunotoxic, teratogenic and carcinogenic 36 effects (Höhler et al. 1998; Pfohl-Leszkowicz and Castegnaro 1999). Its existence in coffee 37 was reported for the first time by Levi et al. (1974). Since then, a great deal of work has been 38 undertaken to study what happens to the toxin during technological processing of coffee, such 39 as roasting and beverage preparation (Viani 1996; Blanc et al. 1998; Van der Stegen et al. 40 2001). Some work has indicated a higher OTA content in the beverage (prepared hot) 41 compared to that found in the roasted coffee used for beverage preparation (Tsubouchi et al. 42 1987; Studer-Rohr et al. 1995; Suàrez-Quiroz et al. 2005,). As the usual method used to 43 quantify OTA in roasted coffee (European Union method prEN 14132: 2002 E) recommends 44 extraction at ambient temperature, it was important to study how temperature and duration 45 influenced OTA extraction. The purpose of this work was therefore to describe the effect of 46 different factors ( $\mathrm{pH}$, temperature, time) that may affect the OTA extraction in roasted coffee.

$48 \quad$ Material and Methods

49 Coffee

50 The experiments were performed on samples of commercially available roasted, ground 51 coffee. 
54 Extraction was carried out in an alkaline solvent $(\mathrm{pH} \mathrm{9,4)} \mathrm{consisting} \mathrm{of} \mathrm{methanol} \mathrm{and} \mathrm{sodium}$

55 bicarbonate at $3 \%(20 / 80 ; \mathrm{v} / \mathrm{v})$, in a neutral solvent $(\mathrm{pH} \approx 6,5)$ consisting of methanol and

56 distilled water (20/80; v/v) and in an acid solvent ( $\mathrm{pH} 4,3)$ consisting of methanol and

57 Titrinorm ${ }^{\circledR}$ pH4 buffer (20/80; v/v) (VWR Prolabo, Fontenay sous Bois, France). Extraction

58 was carried out either at ambient temperature $\left(23^{\circ} \mathrm{C}\right)$, or in a moderately $\left(60^{\circ} \mathrm{C}\right)$ or more

59 heated medium $\left(85^{\circ} \mathrm{C}\right)$, with extraction times of 5, 20, 30, 40, 50, 60 and 80 min. Extraction

60 at $85^{\circ} \mathrm{C}$ required the use of a refrigerant to limit losses through evaporation, and pumice

61 stones for stirring during boiling.

62 The basic OTA quantification method used was that published by Pittet et al. (1996) for 63 soluble coffee, an adaptation of the method developed by Nakajima et al. (1990). The sample

64 of roasted coffee $(10 \mathrm{~g})$ was extracted at ambient temperature for $30 \mathrm{~min}$ with $100 \mathrm{ml}$ of 65 alkaline solvent. For that study and all the extraction variants, the filtered extract (5 ml) was 66 diluted in $40 \mathrm{ml}$ of alkaline phosphate buffer (PBS) and the mixture was purified on an 67 immuno-affinity column (Ochraprep ${ }^{\circledR}$, Rhône Diagnostics, Glasgow, UK). The toxin was 68 eluted from the column with $3 \mathrm{ml}$ of methanol and the eluant was evaporated till dry in a 69 stream of nitrogen at $70^{\circ} \mathrm{C}$. The dry extract was re-suspended in $1 \mathrm{ml}$ of mobile phase 70 consisting of distilled water, acetonitrile and acetic acid (51/48/1; v/v/v). Quantification was 71 carried out by HPLC (Shimadzu LC-10ADVP, Japan) with fluorimetric detection. The 72 operating conditions were as follows: $100 \mu \mathrm{l}$ injection loop, C18 reverse phase HPLC 73 column, ODS particle size $5 \mu \mathrm{m}$ (Lichrospher 50DS2, Interchim, Montluçon, France) with 74 identical precolumn, thermostatically controlled at $35^{\circ} \mathrm{C}$, isocratic flow of $1 \mathrm{ml} / \mathrm{min}$, excitation 75 wavelength of $333 \mathrm{~nm}$ and emission wavelength of $460 \mathrm{~nm}$. The contents were calculated 76 from a calibration curve established from a standard (1 $000 \mathrm{ng} \mathrm{ml}^{-1}$; ref PD $226 \mathrm{R}$. Biopharm 
77 Rhône Ltd, Glasgow, UK).

78 Each extraction and quantification was performed respectively two and three times and the

79 results presented in the form of mean and standard deviation. The limit of quantification of 80 the method is $0.03 \mu \mathrm{g} \mathrm{kg}^{-1}$.

\section{Results and discussion}

83 Extraction in an alkaline medium

84 Figure 1 shows the curves for OTA extraction in an alkaline medium, depending on the 85 temperature and extraction time, for a first batch of coffee. The extraction method 86 recommended by the European Union was carried out at ambient temperature for $30 \mathrm{~min}$. 87 OTA quantification by that method gave a content equal to $10.5 \pm 0.3 \mu \mathrm{g} \mathrm{kg}^{-1}$. At the same 88 temperature, other extraction times gave no change in the amount of OTA quantified. 89 However, when extraction was carried out at $60^{\circ} \mathrm{C}$, it was clearly improved and then 90 depended on the extraction time. The extraction curve passed through a maximum

$91\left(31.0 \pm 0.3 \mu \mathrm{g} \mathrm{kg}^{-1}\right)$ at $50 \mathrm{~min}$. A decrease then set in, which was may be linked to OTA 92 degradation or more probably complexing of OTA. Compared to extraction at ambient 93 temperature, a maximum extraction improvement of $195 \%$ was obtained. At $85^{\circ} \mathrm{C}$, OTA 94 content decreased immediately and continually in line with the heating time. That decrease 95 was a sign of OTA degradation or complexation, which was immediate and probably became 96 preponderant compared to the gain in extraction.

$97 \quad$ [Insert Figure 1 about here]

98

99 Extraction in a neutral medium 
100 The curves for OTA extraction in a neutral medium depending on the temperature and 101 extraction time are shown in Figure 2 for the same batch of coffee. As in the alkaline medium, 102 OTA extraction in a neutral medium at $23^{\circ} \mathrm{C}$ gave results that remained almost constant, 103 irrespective of the extraction time, and which were almost identical $\left(10.3 \pm 0.5 \mu \mathrm{g} \mathrm{kg}^{-1}\right)$, the

104 difference in extraction falling within the sensitivity limit of the method $\left(0.03 \mu \mathrm{g} \mathrm{kg}^{-1}\right)$. 105 Consequently, at ambient temperature, there was no significant difference depending on 106 whether extraction was carried out in an alkaline or neutral medium. At $60^{\circ} \mathrm{C}$, we found a 107 gradual and continual rise in OTA content in line with the extraction time. After 80 min, the 108 content extracted was $24.4 \pm 0.2 \mu \mathrm{g} \mathrm{kg}^{-1}$. The extraction improvement was therefore $137 \%$

109 compared to ambient temperature, but the amount extracted was smaller than that obtained in 110 an alkaline medium. At $85^{\circ} \mathrm{C}$, the quantities extracted increased in line with the extraction 111 time, up to $50 \mathrm{~min}$. At that extraction maximum, the OTA content was $23.1 \pm 0.1 \mu \mathrm{g} \mathrm{kg}^{-1}$, 112 which was greater than for extraction at ambient temperature, but was still below the 113 maximum obtained in an alkaline medium.

114 [Insert Figure 2 about here]

116 Extraction in an acid medium

117 Figure 3 gives the curves for OTA extraction in an acid medium for the same batch of coffee. 118 Extraction at ambient temperature gave quite constant values with a maximum value of $6.4 \pm$ $1191.1 \mu \mathrm{g} \mathrm{kg}^{-1}$. Heating improved the quantities extracted, but the values remained below those 120 obtained with the alkaline and neutral solvents under the same conditions.

121 [Insert Figure 3 about here] 
122 OTA extraction in a neutral or acid medium did not therefore show any particular 123 improvement compared with that obtained in an alkaline medium. The best extraction rate 124 was obtained with the alkaline solvent at $60^{\circ} \mathrm{C}$ after $50 \mathrm{~min}$. In order to confirm the fact that 125 extraction at ambient temperature was incomplete, a double extraction assay was performed 126 on a second batch of coffee.

128 Double extraction

129 The residue resulting from OTA extraction by the usual method (ambient temperature, i.e. $13023^{\circ} \mathrm{C}$ for $30 \mathrm{~min}$ ) was recovered and re-quantified under optimum conditions, i.e. at $60^{\circ} \mathrm{C}$ for $13150 \mathrm{~min}$. The OTA content found for the first extraction was $16.5 \pm 0.2 \mu \mathrm{g} \mathrm{kg}^{-1}$ (higher content 132 than for the first batch of coffee), whereas that found in the residue after the second extraction 133 was $9.1 \pm 0.1 \mu \mathrm{g} \mathrm{kg}^{-1}$, i.e. a total of $25.6 \mu \mathrm{g} \mathrm{kg}^{-1}$. Direct extraction at $60^{\circ} \mathrm{C}$ gave $26.1 \pm 0.6 \mu \mathrm{g}$ $134 \mathrm{~kg}^{-1}$ for the same batch. These results show that OTA extraction conditions at $23^{\circ} \mathrm{C}$ were not 135 optimum and largely underestimated the OTA content. Both the temperature and the 136 extraction time were inadequate.

137

\section{Verification of the method on several samples of roasted coffee}

139 Twenty-four different brands of roasted, ground coffee were bought commercially and 140 quantified using the method recommended by the EU (alkaline solvent at $23^{\circ} \mathrm{C}$ for $30 \mathrm{~min}$ ) 141 and the alternative method proposed (alkaline solvent at $60^{\circ} \mathrm{C}$ for $50 \mathrm{~min}$ ). Table 1 gives the 142 results of a comparison between the two extraction methods on samples of roasted coffee.

143 [Insert Table 1 about here] 
144 An improvement in OTA extraction, ranging from 100 to 200\%, was obtained with the new

145 method for all the coffee samples contaminated with OTA. The degree of improvement in the 146 extraction rate obtained with the new method varied from sample to sample. That variation 147 could be explained by the type of coffee (arabica, robusta, or blend) and the degree of roasting 148 (light, medium, dark). During roasting, reactions leading to reversible chelation of OTA with 149 other molecules such as proteins can occur (Il'ichev et al. 2002). Figure 4 shows a 150 chromatograms of a commercial sample of roasted coffee, a same spiked sample (with $2,5 \mu \mathrm{g}$ $151 \mathrm{~kg}^{-1}$ added), and a sample of coffee beverage.

152 [Insert Figure 4 about here]

153

154 The purpose of this study was to explain the increase in OTA content found in a coffee 155 beverage compared to that in the roasted coffee used to prepare it. The increase was due to the 156 operating conditions used. The solvent $(\mathrm{pH})$, temperature and extraction time affected the 157 OTA content obtained. The EU method (alkaline solvent at ambient temperature for $30 \mathrm{~min}$ ) 158 gave unsatisfactory OTA extraction rates. Alkaline solvent was best for extracting OTA from 159 roasted coffee, provided it was extracted at $60^{\circ} \mathrm{C}$ for $50 \mathrm{~min}$. An improvement of at least $160100 \%$ was observed. The results of OTA analysis in roasted coffee or the beverage by the 161 conventional technique therefore need to be treated with caution. As the legislation fixes a 162 tolerable limit of $5 \mu \mathrm{g} \mathrm{kg}^{-1}$, it would be advisable to revise the analysis conditions. 163

\section{Acknowledgements}


165 Thanks to the Service for Cooperation and Cultural Action at the French Embassy in 166 Cameroon for funding this work.

167

168 References

169 Anonymous 2005. Determination of ochratoxin A in barley and roasted coffee - HPLC 170 method with immunoaffinity column clean-up. Ref $\mathrm{N}^{\circ}$ prEN 14132:2002 E. CEN B-1050 171 Brussels.

172 Blanc M, Pittet A, Munoz-Boz R, Viani R. 1998. Behaviour of ochratoxin A during green 173 coffee roasting and soluble coffee manufacture. Journal of Agricultural and Food Chemistry 174 46: 673-675.

175 Frank JM. 2001. On the activity of fungi in coffee in relation to Ochratoxin A production. $19^{\text {th }}$ 176 ASIC Coffee Conference, Trieste, Italy. 14-18 May 2001. Available : http://www.asic177 cafe.org/htm/eng/proceedings.htm.

178 Höhler D. 1998. Ochratoxin A in food and feed: occurrence, legislation and mode of action. 179 Zeitschrift für Ernäh rungswissenschaft 37: 2-12.

180 Il'ichev YV, Perry JL, Rüker F, Dockal M, Simon JD. 2002. Interaction of Ochratoxin A with 181 human serum albumin. Binding sites localized by competitive interactions with the native 182 protein and its recombinant fragments. Chemico-Biological Interactions 141: 275-293. 
183 Joosten HM, Goetz J, Pittet A, Schellenberg M, Bucheli P. 2001. Production of Ochratoxin A 184 by Aspergillus carbonarius on coffee cherries. International Journal of Food Microbiology 185 65: 39-44.

186 Levi CP, Trenk HL, Mohr HK. 1974. Study of the occurrence of Ochratoxin A in green coffee 187 beans. AOAC Journal 57: 866-870.

188 Nakajima M, Terada H, Hisada K, Tsubouchi H, Yamamoto K, Uda T, Itoh Y, Kawamura O, 189 Ueno Y. 1990. Determination of Ochratoxin A in coffee beans and coffee products by 190 monoclonal antibody affinity chromatography. Food and Agricultural Immunology 2: 189191195.

192 Pfohl-Leszkowicz A, Castegnaro M. 1999. L'Ochratoxine A. In: Les mycotoxines dans 193 l'alimentation: Evolution et gestion des risques. Pfohl-Leszkowicz A, editor. Lavoisier, Paris. 194 pp. 249-277.

195 Pittet A, Tonare D, Huggett A, Viani R. 1996. Liquid chromatographic determination of 196 Ochratoxin A in pure adulterated soluble coffee using an immuno-affinity column cleanup 197 procedure. Journal of Agricultural and Food Chemistry 44: 3564-3569.

198 Studer-Rohr I, Dietrich DR, Schlatter J, Schlatter C. 1995. The occurrence of Ochratoxin A in 199 coffee. Food Chemistry and Toxicology 33: 341-355.

200 Suàrez-Quiroz ML, Gonzáles-Rios O, Barel M, Guyot B, Schorr-Galindo S, Guiraud JP. 201 2004. Study of Ochratoxin A producing strains in coffee processing. International Journal of 202 Food Science and Technology 39: 501-507. 
203 Suàrez-Quiroz ML, De Louise B, Gonzáles-Rios O, Barel M, Guyot B, Schorr-Galindo S, 204 Guiraud JP. 2005. The impact of roasting on the Ochratoxin A content of coffee. International 205 Journal of Food Science and Technology 40: 605-611.

206 Tsubouchi H, Yamamoto K, Hisada K, Sakabe Y, Udagawa S. 1987. Effect of roasting on 207 Ochratoxin A level in green coffee beans inoculated with Aspergillus ochraceus. 208 Mycopathologia 97: 111-115.

209 Van der Stegen GHD, Essens PJM, Van der Lijn J. 2001. Effect of roasting conditions on 210 reduction of Ochratoxin A in coffee. Journal of Agricultural and Food Chemistry 49: 47132114715.

212 Viani R. 1996. Fate of Ochratoxin A (OTA) during processing of coffee. Food Additives and 213 Contaminants 13 (suppl.): 29-33. 


\section{$214 \quad$ Figure captions}

215 Figure 1. Effect of temperature and extraction time on OTA extraction in an alkaline solvent

216 Figure 2. Effect of temperature and extraction time on OTA extraction in a neutral solvent

217 Figure 3. Effect of temperature and extraction time on OTA extraction in an acid solvent

218 Figure 4. HPLC chromatograms of : commercial sample of roasted coffee, spiked sample with

$2192.5 \mu \mathrm{g}$ OTA $\mathrm{kg}^{-1}$ added, coffee beverage sample

220 


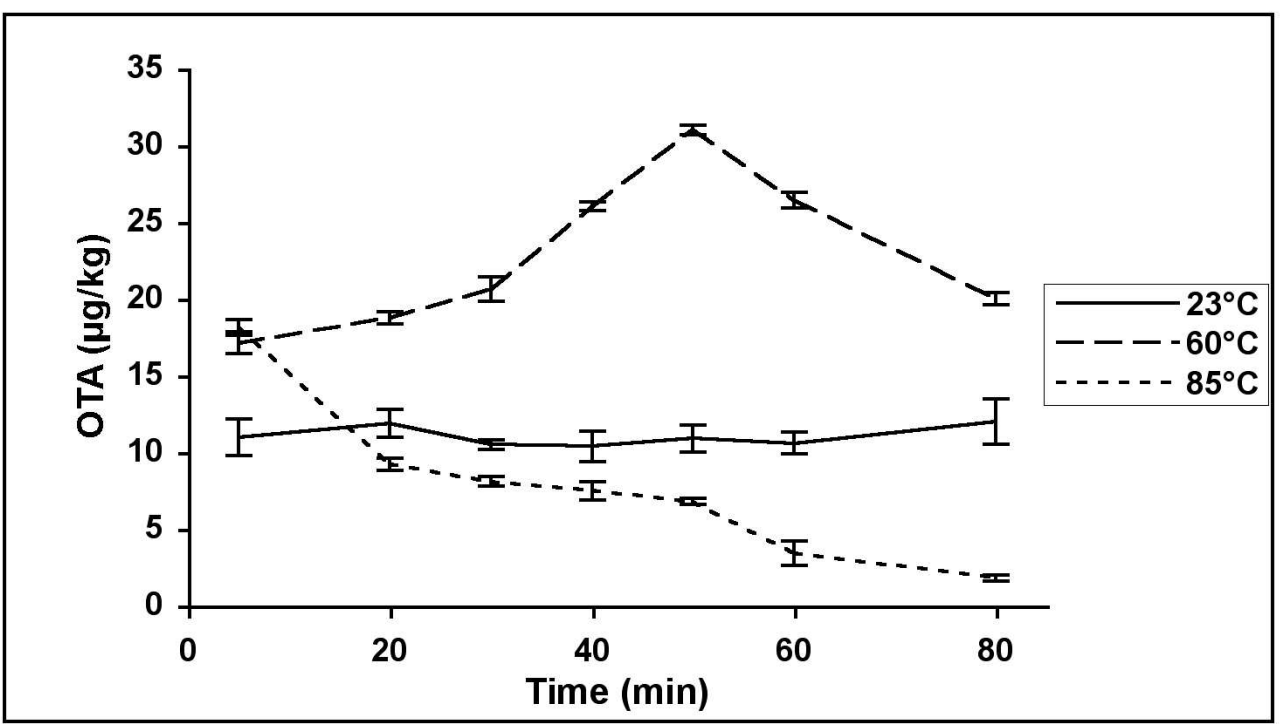

Effect of temperature and extraction time on OTA extraction in an alkaline solvent $126 \times 71 \mathrm{~mm}(300 \times 300 \mathrm{DPI})$ 
Effect of temperature and extraction time on OTA extraction in a neutral solvent $126 \times 72 \mathrm{~mm}(300 \times 300$ DPI $)$ 


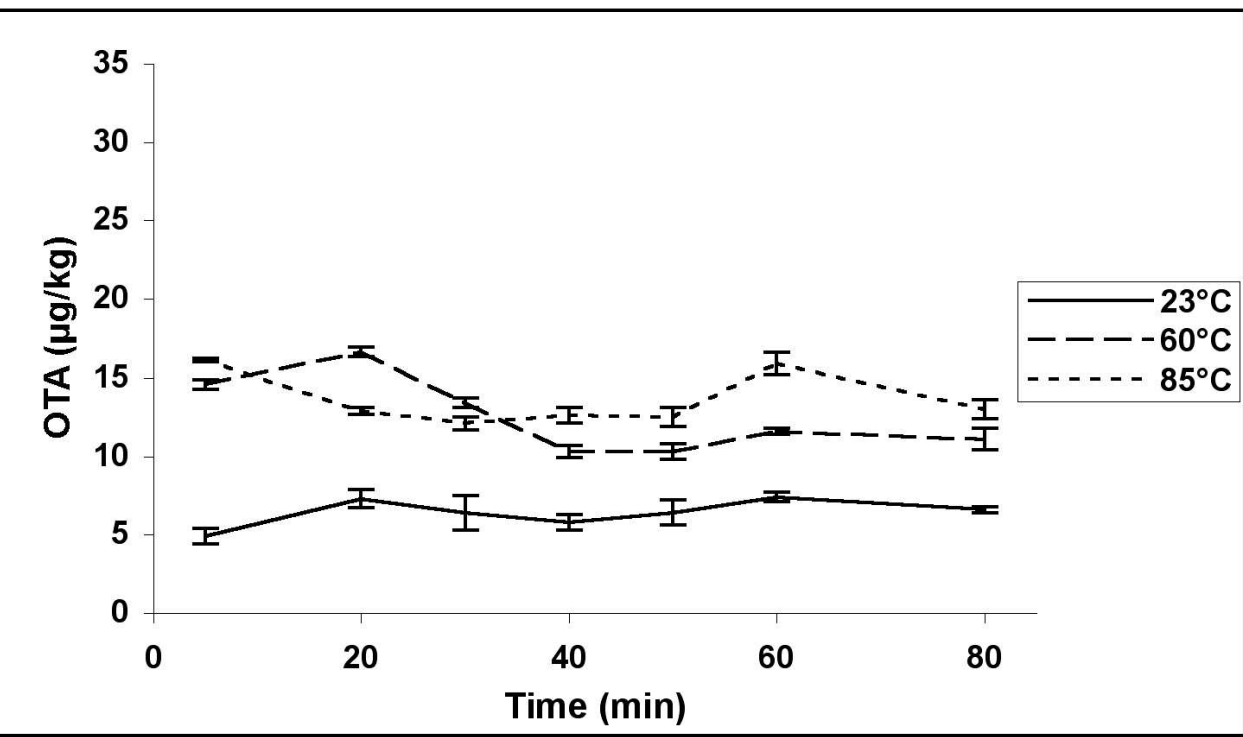

Effect of temperature and extraction time on OTA extraction in an acid solvent $127 \times 74 \mathrm{~mm}(300 \times 300 \mathrm{DPI})$ 


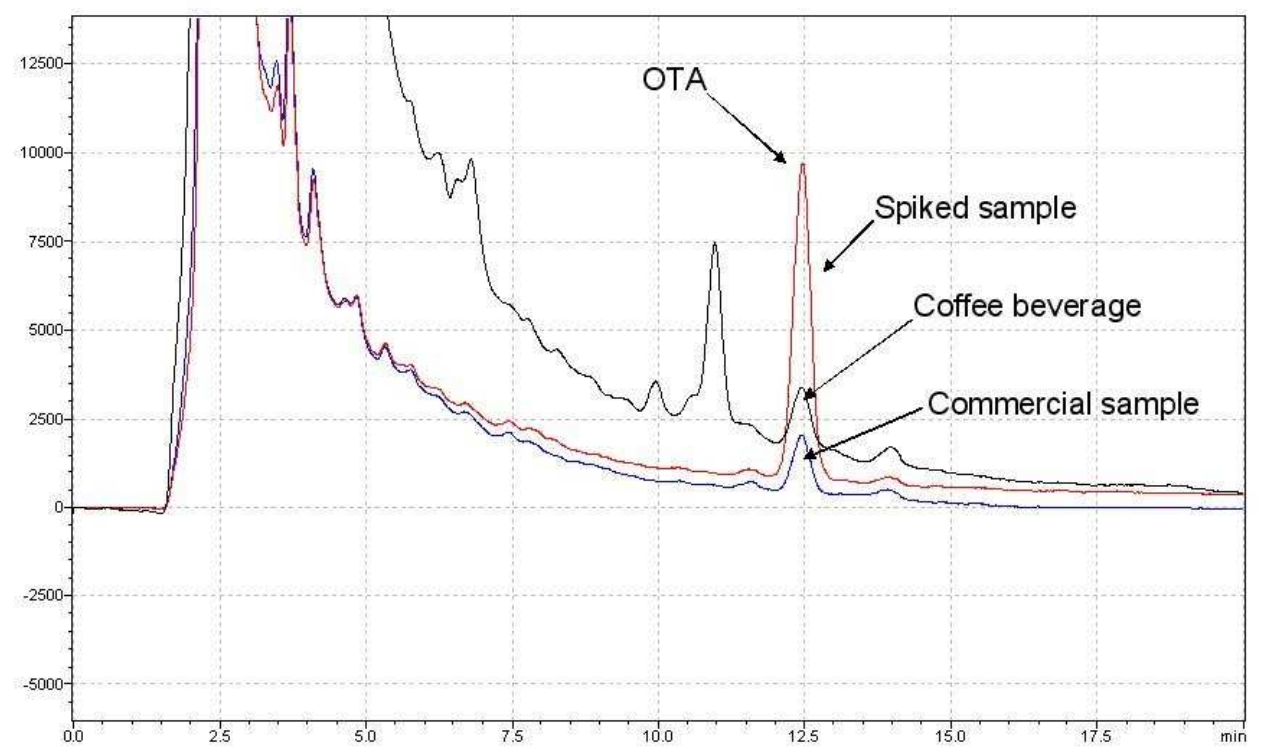

HPLC chromatograms of commercial sample of roasted coffee, spiked sample with $2.5 \mu \mathrm{g}$ OTA $\mathrm{kg}-1$ added, coffee beverage sample $239 \times 140 \mathrm{~mm}(96 \times 96 \mathrm{DPI})$ 